\title{
The Effect of Computer Anxiety, Computer Attitude, Computer Self Efficacy and Accounting Knowledge on Accounting Students' Understanding Using Accurate-based Accounting Software
}

\author{
Sarwenda Biduri* \\ Acounting Deartment \\ Muhammadiyah Sidoarjo University \\ Sidoarjo, Indonesia \\ *sarwendabiduri@umsida.ac.id
}

\author{
Sigit Hermawan, Eny Maryanti, Ruci Arizanda \\ Rahayu, Nikmatul Utami \\ Muhammadiyah Sidoarjo University \\ Sidoarjo, Indonesia \\ enymaryanti@umsida.ac.id, sigithermawan@umsida.ac.id, \\ ruci_rahayu@umsida.ac.id
}

\begin{abstract}
This research aimsat knowing computer anxiety variables, computer attitude variables, computer self-efficacy variables, and accounting knowledge variables, which can affect student understanding using accurate based software. This type of research used quantitative research. The sample used was $\mathbf{1 3 4}$ accounting students in 2017 using probability sampling and random sampling methods - the data obtained by distributing questionnaires to students majoring in accounting to answer. The analysis tool was used to help process datain SPSS software version 18.0. The analysis technique uses multiple linear. There were 134 copies of the questionnaire distributed; only 129 were returned and could be processed. The research limitation was only to test four variables and was carried out on the 5th semester accounting students of Muhammadiyah University of Sidoarjo. The research contribution to the problem is to examine four internal factors that influence student understanding using a computer accounting program. The results of the partial test show that the computer anxienty variable (X1) and the computer attitude variable (X2) have no effect on understanding using accurate software. But the computer self-efficacy variable (X3) and the accounting knowledge variable (X4) partially affect the understanding of accounting students using accurate accounting software.
\end{abstract}

Keywords - computer anxiety, computer attitude, computer selfefficacy, accounting knowledge, accurate accounting software

\section{INTRODUCTION}

Globalization and modernization make technology an inseparable part of human life. The Industry 4.0 era affects many aspects of life, ranging from economy, politics, culture, art, to education. For the state, this phenomenon raises three threats, namely an increase in the unemployment rate, the conversion of human labor to machines, and the focus of companies on being capital intensive rather than working for the nation. As an implication, universities must produce reliable graduates with technology as a means to support the learning process and expected learning outcomes. Specifically, the accounting department must implement a computer accounting curriculum by utilizing software so that students are better prepared for real-world jobs. Students need to become familiar with accounting software and help them develop literacy, critical thinking, and analytical skills because these factors are important assets in facing competition. Almost all accounting activities in companies use the accounting system as a regulator of work activities and all instructions that lead to computers. In connection with technological changes, which are also related to changes in computer applications, many organizations and employees rely on the use of computers as the main medium for completing tasks (data entry and processing) [1]. One of the accounting systems that can be used is Accurate software, which helps someone save time in doing bookkeeping, selling and buying processes, accounts payable, and other transactions. Therefore, accounting computer courses are essential for students to study.

The American Institute of Certified Accountants (AICPA) has also recently made a certificate namely (CITP) or a certified Information Professional. CITP contains a documentation of the systems expertise of accountants who have extensive knowledge in the field of technology who understands how information technology is used in various organizations or companies. CITP is proof that students who want to become accountants have expertise in technology, it can also trigger students' interest to be more enthusiastic in studying technology, especially to study and use various kinds of accounting software [2]. Despite the well-known and proven advantages of computers, many people still try to avoid using them. It is very important to know the factors that influence the computing success of the end user [3].

However, the learning outcomes achieved by students after taking accounting computer courses vary because there are internal factors that affect students' understanding of using 
accounting computer programs. The lack of understanding of students in the use of accounting software and the existence of various gaps in the results of previous studies, this research was conducted to examine the computer anxiety, computer attitude, computer self-efficacy, and students 'accounting knowledge towards students' understanding of accounting using accounting software Accurate.

\section{METHODS}

\section{A. Research Approach}

This study uses a quantitative research approach. Sugiyono [4] stated that quantitative research methods are used to examine certain populations or samples of collection and use research instruments, analysis, and quantitative/ statistical data. The test aimed to determine hypotheses. The data was processed with several tests to provide conclusions.

\section{B. Research Location}

The research was conducted at Universitas Muhammadiyah Sidoarjo, Jl. Mojopahit 666B Sidoarjo - East Java.

\section{Types and Sources of Data}

The type of data used in this research is quantitative data, which is numerical assessment data. This study uses primary data as a source of data in the form of information obtained directly from the first source that becomes the object.

\section{Population and Sample}

The research population is the number of all objects whose characteristics are to be estimated. Population is the area of generalization of the subject or object of research that has characteristics and qualities that can be determined to be studied and then drawn to conclusions [5]. The population in this study is all students of the Accounting Department of Faculty of Business Law and Social Sciences at Universitas Muhammadiyah Sidoarjo, class of 2017, which has taken 202 computer accounting courses. The sampling process applied a technique that provides an equal opportunity or opportunity for each element or member of the population to choose, either as a sample using the simple random sampling method or simple random sampling and the Slovin formula as follows:

$$
\begin{gathered}
n=\frac{N}{1+n(e)^{2}} \\
n=\frac{202}{1+202(0.05)^{2}} \\
n=\frac{202}{1+0.505} \\
\mathrm{n}=134
\end{gathered}
$$

Information:

$\mathrm{n}=$ Sample size / Number of respondents

$$
\begin{aligned}
& \mathrm{N}=\text { total population } \\
& \mathrm{e}=\text { Percentage of error }=5 \%
\end{aligned}
$$

\section{E. Data Analysis Methods}

This research used multiple linear regression analysis techniques to determine the relationship between the independent variable and the dependent variable. Validity test, reliability test, and hypothesis testing were carried out with the help of SPSS version 18.0 software [6] . Descriptive statistics are statistics used to analyze data by describing or describing the data that has been collected, without intending to make conclusions, which apply to the general public or generalizations.

\section{RESULTS AND DISCUSSION}

\section{A. Description of the Research Sample}

The research sample description serves to provide an overview or description of the data.

TABLE I. QUESTIONNAIRE RETURN RATE

\begin{tabular}{|l|l|l|}
\hline No & \multicolumn{1}{|c|}{ Details } & \multicolumn{1}{c|}{ Numbers } \\
\hline 1 & Number of questionnaires distributed & 134 a copy \\
\hline 2 & Number of non-returned questionnaires & Two a copy \\
\hline 3 & Number of questionnaires returned & 132 a copy \\
\hline 4 & The number of unusable questionnaires & Three a copy \\
\hline 5 & Number of questionnaires used & 129 a copy \\
\hline
\end{tabular}

This research was conducted at the University of Muhammadiyah Sidoarjo in accounting study program students in 2017 who have taken computer accounting courses (accurate) with 202 total respondents who were then formulated using the Slovin formula to become 135 respondents only.

\section{B. Respondent Based on Gender}

The first characteristic is the characteristic based on gender which can be seen in the table presentation below:

TABLE II. RESPONDENT CHARACTER BASED ON GENDER

\begin{tabular}{|c|c|l|l|l|l|}
\hline & Frequency & Percent & $\begin{array}{c}\text { valid } \\
\text { Percent }\end{array}$ & $\begin{array}{c}\text { Cumulative } \\
\text { percent }\end{array}$ \\
\hline valid & man & 28 & 21.7 & 21.7 & 21.7 \\
\hline & woman & 101 & 78.3 & 78.3 & 100.0 \\
\hline & Total & 129 & 100.0 & 100.0 & \\
\hline
\end{tabular}

The table 2 shows that male respondents are less than female respondents. The percentage of male respondents was $21.7 \%$, while female respondents were $78.3 \%$. Equations

\section{Respondent Age}

The second characteristic of the respondent is the characteristic based on age which can be seen in the table 3 presentation below: 
TABLE III. RESPONDENT CHARACTERISTICS BASED RESPONDENTS' AGE

\begin{tabular}{|c|l|l|l|l|}
\hline & Frequency & Percent & $\begin{array}{c}\text { Valid } \\
\text { Percent }\end{array}$ & $\begin{array}{c}\text { Cumulative } \\
\text { Percent }\end{array}$ \\
\hline <20 year & 3 & 2.3 & 2.3 & 2.3 \\
\hline$>$ 22 year & 14 & 10.9 & 10.9 & 13.2 \\
\hline 20-22 year & 112 & 86.8 & 86.8 & 100.0 \\
\hline total & 129 & 100.0 & 100.0 & \\
\hline
\end{tabular}

Table 3 shows that there are more respondents aged 20-22. The percentage of respondents aged $<20,>22$, and between 20 22 are $.2 .3 \%, 10.9 \%$, and $86.8 \%$, respectively.

\section{Data Quality Test}

The data quality test included validity and reliability test.

1) Validity test: The validity test shows whether the questionnaire is valid or not. The questionnaire can be declared valid if the questionnaire can be used to measure its function and the results are as follows table 4:

TABLE IV. VALIDITY STATISTICS

\begin{tabular}{|l|l|l|l|l|}
\hline No & Code & $\begin{array}{c}\text { Corrected item-total } \\
\text { correlation }\end{array}$ & Constrac & Information \\
\hline 1 & XI_1 & 0,668 & 0,3 & Valid \\
\hline 2 & XI_2 & 0,707 & 0,3 & Valid \\
\hline 3 & XI_3 & 0,641 & 0,3 & Valid \\
\hline 4 & XI_4 & 0,649 & 0,3 & Valid \\
\hline 5 & XI_5 & 0,518 & 0,3 & Valid \\
\hline 6 & XI_6 & 0,412 & 0,3 & Valid \\
\hline 7 & XI_7 & 0,401 & 0,3 & Valid \\
\hline 8 & XI_8 & 0,341 & 0,3 & Valid \\
\hline 9 & XI_9 & 0,373 & 0,3 & Valid \\
\hline 10 & XI_10 & 0,377 & 0,3 & Valid \\
\hline
\end{tabular}

2) Reliability test: This reliability test determines the level of reliability (reliability) of a questionnaire with the following results:

TABLE V. RELIABILITY STATISTICS

\begin{tabular}{|l|l|}
\hline Cronbach's Alpha & N of Items \\
\hline 705 & 10 \\
\hline
\end{tabular}

Some Common Mistakes

- The word "data" is plural, not singular.

- The subscript for the permeability of vacuum $\mu_{0}$, and other common scientific constants, is zero with subscript formatting, not a lowercase letter "o."

- In American English, commas, semi-/colons, periods, question, and exclamation marks are located within quotation marks only when a complete thought or name is cited, such as a title or full quotation. When quotation

- The results of the calculation of the reliability test in the Statistical Reliability table show that the Cronbach Alpha value of the X1 statement is 0.705 or from 0.600 so that $\mathrm{X} 1$ is declared reliable. Meanwhile, the validity test $\mathrm{X} 1 \_1$ to $\mathrm{X} 1 \_10$ shows the results that all questionnaire statement items are declared valid. The item-total correlation for all statement items X1 is more than 0.3

\section{E. Hypothesis Test}

1) Multiple regression: Multiple regression analysis was used to determine regression coefficients and signification so that it can be used to answer the hypothesis.

TABLE VI. RESUlts OF MULTIPLE LINEAR REGRESSION ANALYSIS

\begin{tabular}{|c|c|c|c|c|c|c|c|c|}
\hline & \multicolumn{8}{|c|}{ Coefficients* } \\
\hline & \multirow[t]{2}{*}{ Model } & \multicolumn{2}{|c|}{ Unstandardize } & \multirow{2}{*}{$\frac{\text { Standardize }}{\text { Beta }}$} & \multirow[t]{2}{*}{$\mathbf{t}$} & \multirow[t]{2}{*}{ Sig. } & \multicolumn{2}{|c|}{ Collinearity } \\
\hline & & B & Std. & & & & Tolera & $V I F$ \\
\hline 1 & (Constant) & 8,09 & 2,929 & & 2,764 & ,007 & & \\
\hline & Computer & ,029 &, 059 & ,038 & ,499 & ,619 & ,867 & 1,153 \\
\hline & Computer & ,006 &, 051 & ,010 &, 124 & 902 & ,792 & 1,262 \\
\hline & $\begin{array}{l}\text { Computer } \\
\text { Selft }\end{array}$ & ,521 & ,089 & ,433 & 5,870 & ,000 & ,918 & 1,090 \\
\hline & Knowledge & 1,10 & , 167 & ,505 & 6,633 & ,000 & ,861 & 1,162 \\
\hline
\end{tabular}

$Y=8,097+0,029 X_{1}+0,006 X_{2}+0,521 X_{3}+1,109 X_{4}$

From the results of the equation above, it means that:

- The constant value is 8,097 . It means that without the influence of variables, the value of the dependent variable, namely the understanding of the use of accurate accounting software (Y), is 8,097.

- The regression coefficient value of computer anxiety (X1) is 0.029 which means that if there is a one-unit increase in the computer anxiety variable (X1), as long as other independent variables are considered constant, it can lead to an increase in the understanding of the variable using accurate accounting software (Y) of 0.029

- The regression coefficient value of computer attitude (X2) is 0.006 . It means that if there is an increase in one unit of the computer attitude variable (X2), it will cause an increase in the understanding variable use of accurate accounting software (Y) of 0.006, as long as other independent variables are considered constant

- The regression coefficient value for computer selfefficacy (X3) is 0.521 . This means that if there is an increase in one unit of the computer self-efficacy variable, it will cause an increase in the understanding variable of using Accurate software (Y) by 0.521, provided that other independent variables are considered constant.

- The regression coefficient value of accounting knowledge (X4) is 1.109 . This means that if there is an increase in one unit of accounting knowledge variable, then this will result in an increase in the understanding variable of using Accurate software (Y) of 1.109 provided that the other independent variables are constant. 


\section{2) Correlation coefficient test}

TABLE VII. TABLE CORRELATION COEFFICIENT

\begin{tabular}{|c|c|c|c|c|c|}
\hline \multicolumn{6}{|c|}{ Model Summary $^{\mathbf{b}}$} \\
\hline Model & R & R Square & $\begin{array}{l}\text { Adjusted } \\
\text { R Square }\end{array}$ & $\begin{array}{c}\text { Std. } \\
\text { Error of } \\
\text { Estimate }\end{array}$ & $\begin{array}{c}\text { Durbin- } \\
\text { Waston }\end{array}$ \\
\hline dimensi 1 & $.618^{\mathrm{a}}$ &, 382 &, 362 & 2,74589 & 2,049 \\
\hline
\end{tabular}

The value of the correlation coefficient $(\mathrm{R})$ is 0.618 , close to 1 . This means that there is a strong and indirect relationship between the independent variables, which includes computer anxiety (X1), computer attitude (X2), computer self-efficacy (X3), and accounting knowledge (X4) with the dependent variable, namely understanding using Accurate software(Y).

\section{F. Coefficient of Determination $R$ Square (R2)}

The coefficient of determination R square (R2) of 0.382 is $38.2 \%$. This means that the influence of the variable computer anxiety (X1), computer attitude (X2), computer self-efficacy (X3), and accounting knowledge (X4) on the variable understanding of students majoring in accounting at the University of Muhammadiyah Sidoarjo using accurate accounting software (Y) is only $38.2 \%$. In comparison, other variables influence the rest $(100-38.2=61.8 \%)$.

\section{G. G. T-test}

The t-statistical test basically shows the influence of one independent variable individually in explaining the dependent variable.

TABLE VIII. T-STATISTICAL TEST

\begin{tabular}{|c|c|c|c|c|c|c|c|c|}
\hline & \multicolumn{8}{|c|}{ Coefficients* } \\
\hline & \multirow[t]{2}{*}{ Model } & \multicolumn{2}{|c|}{ Unstandardize } & \multirow{2}{*}{$\frac{\text { Standardize }}{\text { Beta }}$} & \multirow[t]{2}{*}{$\mathbf{t}$} & \multirow[t]{2}{*}{ Sig. } & \multicolumn{2}{|c|}{ Collinearity } \\
\hline & & B & Std. & & & & Tolera & $V I F$ \\
\hline 1 & (Constant) & 8,09 & 2,929 & & 2,764 & 007 & & \\
\hline & Computer &, 029 &, 059 & ,038 & ,499 & 619 & 867 & 1,153 \\
\hline & Computer &, 006 & ,051 &, 010 &, 124 & ,902 & ,792 & 1,262 \\
\hline & $\begin{array}{l}\text { Computer } \\
\text { Selft }\end{array}$ &, 521 & ,089 & ,433 & 5,870 & ,000 & ,918 & 1,090 \\
\hline & Knowledge & 1,10 & 167 & ,505 & 6,633 & ,000 & ,861 & 1,162 \\
\hline
\end{tabular}

\section{H. Discussion}

- Based on the results of the t-test, the computer anxiety variable $(\mathrm{X} 1)$ has a t-count value of 0.499 , with a significance value obtained of 0.619 so that ( $t$-count $<\mathrm{t}-$ table $=0.499<1.979$ ) this $\mathrm{t}$-count value is smaller. Based on the t-table value, and ( $\operatorname{sig}>\alpha=0.619>0.05)$, $\mathrm{Ho}$ is accepted and $\mathrm{Ha}$ is rejected. In other words, there is no effect on computer anxiety (X1) on understanding using Accurate software (Y). The results of the study are consistent with the results of research from Maharani [7] which states that computer anxiety has no effect on the expertise in using accounting software in students majoring in accounting at Mahasaraswati University Denpasar. different from the results of research from Aprilina [8] which states that Computer
Anxiety has a positive effect on the Interest of Accounting Students in Using Accounting Software.

- The results of the t-test conducted on the computer attitude variable (X2) show the t-count of 0.124 with a significance value of 0.902 . So with $\mathrm{t}$-count $<\mathrm{t}$ table $=$ $0.124<1.979$, this $\mathrm{t}$-count value is smaller than the ttable value of 1.979, and ( $\mathrm{sig}>\alpha=0.902>0.05$ ). Therefore, Ho is accepted and Ha is rejected, or there is no influence on computer attitudes (X2) on accurate understanding using software (Y). These results are consistent with the results of research from [8] which states that there is no positive and significant influence of computer attitudes on student interest in using accounting software for Yogyakarta state university students. In contrast to the results of research conducted by Candra [9] which states that computer attitude affects expertise in using accurate software.

- The t-test result on the computer self-efficacy variable (X3) shows the t-count of 5.870. The significant value obtained is 0.000 , so (tcount $>$ ttable $=5.870>1.973$ ) this t-count value is greater than the t-table value, namely 1.973 and $(\operatorname{sig}<\alpha=0.000<0.05)$. As a result, Ho is rejected and Ha is accepted, or there is an effect of computer self-efficacy (X3) on understanding using Accurate software (Y). The results of this study are consistent with the results of research conducted by Aprilina [8] showing that there is a significant positive effect of computer self-efficacy on the interest in using accounting software for students of the Accounting Study Program, Faculty of Economics, Yogyakarta State University. different from the results of research from Meirina [10] which state that there is no significant effect between computer operating skills and accounting computer skills.

- The t-test for the variable accounting knowledge (X4) shows the t-count of 6.633 with a significance value of 0.000 . So that ( $t$-count $>t$-table $=6.633>1.973$ ) the value of $\mathrm{t}$ is greater than the t-table value, namely 1.973 and ( $\operatorname{sig}<\alpha=0.000<0.05$ ). In other words, Ho is rejected and $\mathrm{Ha}$ is accepted, or there is an effect of accounting knowledge (X4) on understanding using Accurate software (Y). The results of this study are consistent with the results of research from Lestari [11] which states that there is a significant influence between accounting knowledge and the interest in using zahir software for employees of the accounting department of trading companies in the Sukoharjo district. However, these results are not in line with the results of research by Meirina [10] which state that there is no significant effect between basic accounting knowledge and expertise in using accounting computers.

\section{CONCLUSION}

Based on research and discussion on the effect of "The effect of computer anxiety, computer attitude, computer self- 
efficacy and accounting knowledge on students' understanding of using accurate accounting software, they are as follows:

- Computer anxiety has no effect on understanding using AccuraTe software, this is proven by partial testing that the level of computer anxiety that students have will not affect their understanding of using accurate software, because in times like this technology is increasingly rapid and there are many universities' efforts to make the software familiar. with students, the second conclusion

- Computer attitude has no effect on understanding using accurate accounting software for students of 2017 Muhammadiyah University of Sidoarjo accounting because most accounting students at Muhammadiyah University of Sidoarjo think that accurate accounting computer courses are difficult to understand and have no benefit to study so that their computer attitude level is low. Whereas for

- Computer self-efficacy affects students' understanding of using accurate accounting software for students of Accounting at Muhammadiyah University Sidoarjo, batch 2017. These results can be interpreted that the higher the Muhammadiyah university students have computer self-efficacy, the higher the level of understanding of students in using accurate software.

- Accounting knowledge has an effect on understanding using accurate accounting software based on accounting students at the Muhammadiyah University of Sidoarjo, batch 2017. The higher the level of accounting knowledge that students of Muhammadiyah University of Sidoarjo have, the higher the level of understanding of students in using accurate software, this is because they already have a basic accounting which makes it easy for students to understand the accounting language that is in accurate software and vice versa, the lower their knowledge of the basic accounting basics, the lower their level of understanding using accurate software.

\section{LIMITATIONS}

- This study uses limited respondents, the respondents are only students majoring in accounting at the Faculty of Economics, Muhammadiyah University of Sidoarjo, it is hoped that the next researcher will further expand the respondents because if you use respondents like this research the results are likely to be different if generalized to the next generation

- This study only uses 4 variables, so the limitations of this study are not able to explain all the variables that can affect student understanding using accurate software.

\section{SUGGESTION}

- For the accounting students of the accounting study program of the Economics Faculty of Muhammadiyah University of Sidoarjo who were the samples of this study, it is suggested to continue learning and not easily feel satisfied with what they have learned, students must continue to improve their skills, especially in the various fields of use accounting software. Because do not let accounting students only be good at theory but also experts in using the system.

- For further researchers, it is expected that they seek other factors that have a greater influence on student understanding using accurate software

- For the University of Muhammadiyah Sidoarjo to make computer accounting courses an important subject that must be given to accounting students in addition to accounting theory, universities are also advised to always deepen accurate computer accounting courses and update software that is currently used in various working world.

\section{REFERENCES}

[1] N. Achim and A. Al Kassim A, "Computer usage: the impact of computer anxiety and computer self-efficacy," Procedia-Social Behav. Sci. 172 p. 701-708, 2015.

[2] N. Novianti, "Faktor Faktor yang Mempengaruhi Minat Pemanfaatan Sistem Informasi Berbasis Komputer dengan Gender Sebagai Variabel Moderating," Fakultas Ekonomi dan Bisnis Universitas Brawijaya Malang, 2009.

[3] P. Blignaut, A. Burger, T. McDonald and J. Tolmie, An Overview of Computer Attitude and Anxiety: A Model for Interaction, 1998.

[4] Sugiyono, Metode Penelitian Bisnis. Bandung: Cv Alfabeta, 2017.

[5] I.I. Bahtiar, Pengaruh Penggunaan Fasilitas Laboratorium Akuntansi, Computer Attitude, Dan Motivasi Belajar Terhadap Prestasi Belajar Komputer Akuntansi Myob SMK Palebon Semarang. Universitas Negeri Semarang, 2017.

[6] I. Ghozali, Aplikasi Analisis Multivariate Dengan Program IBM SPSS 23. Semarang: Badan Penerbit Universitas Diponegoro, 2018.

[7] P.N. Maharani, Pengaruh Computer Anxiety Dan Computer Attitude Terhadap Keahlian Pemakaian Software Akuntansi Pada Mahasiswa Jurusan Akuntansi Di Universitas Mahasaraswati Denpasar JSAM (Jurnal Sains, Akunt. dan Manajemen) 1, 2 p. 236-270, 2019.

[8] A.K. Putra, Pengaruh Computer Anxiety, Computer Attitude dan Komputer Self Efficacy terhadap Minat Mahasiswa Akuntansi Menggunakan Software Akuntansi. Universitas Negeri Yogyakarta, Yogyakarta, 2016

[9] R. Candra, Pengaruh computer anxiety dan computer attitude terhadap keahlian dalam menggunakan software accurate, 2018.

[10] E. Meirina and R. Septiano, "Pengaruh Pemahaman Akuntansi Dasar Dan Keahlian Pengoperasian Komputer Terhadap Keahlian Komputer Akuntansi," Jurnal Pundi, Vol. 01 No. 012019.

[11] E. Lestari, Pengaruh Persepsi Kemudahan Penggunaan, Persepsi Kebermanfaatan, Computer Self Efficacy, Faciliting Conditional dan Pengetahuan Akuntansi terhadap Minat Menggunakan Software Zahir. Skripsi. Institut Agama Islam Negeri Surakarta, 2018. 